\section{Cureus}

\title{
A Review of Novel Antidepressants: A Guide for Clinicians
}

\author{
Amber E. Faquih ${ }^{1}$, Raheel I. Memon ${ }^{2}$, Hudaisa Hafeez ${ }^{3}$, Muhammad Zeshan ${ }^{4}$, Sadiq Naveed
} 5

1. Psychiatry, Dow University of Health Sciences, Karachi, PAK 2. Psychiatry, Henry Ford Allegiance Health, Jackson, USA 3. Psychiatry, Duke University Health System, Durham, USA 4. Psychiatry, Bronx Lebanon Hospital Icahn School of Medicine at Mount Sinai, Bronx, USA 5. Psychiatry, Kansas University Medical Center, Kansas, USA

$\square$ Corresponding author: Sadiq Naveed, naveed193@gmail.com

Disclosures can be found in Additional Information at the end of the article

\section{Abstract}

This review article aims to provide insight into the mechanisms of action, pharmacokinetics, clinical efficacy, safety and tolerability of four novel antidepressants including desvenlafaxine, vortioxetine, vilazodone, and levomilnacipran. Following keywords are used in PubMed and Scopus to search for relevant articles: (depression) AND (psychopharmacology OR desvenlafaxine OR levomilnacipran OR vortioxetine OR vilazodone). Patients with a lack of effectiveness or tolerability to certain antidepressants may get benefit from selecting a new antidepressant with different mechanism of action. These medications can be an option in the selection of newer antidepressants. Depression may not be caused by the simple deficiency of serotonin in the brain, but rather a complex interplay of various neurotransmitters including serotonin, norepinephrine, glutamate, and histamine at certain brain areas. The abovementioned novel antidepressants exert their therapeutic benefits by acting on multiple neurotransmitters. The complexity of underlying the neurobiological mechanism should be considered while formulating a plan of care.

Categories: Psychiatry, Other

Keywords: antidepressant, snri, depression, selective serotonin reuptake inhibitors (ssri)

\section{Introduction And Background}

Major depressive disorder (MDD) is a major public health concern with significant impairment in psychological, occupational, and social functioning. The prevalence rates for depression are estimated to be around $3.2 \%$ in patients without comorbid physical illnesses and $9.3 \%$ to $23.0 \%$ in patients with chronic conditions. It is the fourth cause of disability around the world and is estimated to be the second leading cause of disability by 2020 [1]. It affects around 300 million individuals regardless of gender, ethnicity, geographical location, and socioeconomic status, contributing to the overall global burden of disease.

Selective serotonin reuptake inhibitors (SSRIs) are the appropriate first-line options for the treatment of depression along with psychotherapeutic interventions, but many patients either do not respond to different options or intolerant to the undesired effects of medications [2]. Despite multiple treatment regimen, about $60 \%$ of patients with MDD continue to report residual impairments even after treatment [3]. This residual symptoms and functional impairment have a higher risk of relapse into the future episodes of MDD. The debilitating health-related quality of life effects of MDD has an adverse impact on individuals, resulting in 
academic, interpersonal, social, and occupational impairment. Even after achieving remission, depression has higher rates of recurrence in up to $80 \%$ of all MDD patients with odds of becoming chronic in $20 \%$ of patients. The onset of each new major depressive episode increases the chances of relapse, chronicity, and treatment-resistant depression [4].

Different ideas have been postulated to understand the reasons for the ineffectiveness of monoamine modulators for the treatment of depression. The lack of effectiveness can result from poor compliance secondary to the delayed effects of the medications or undesired effects such as sexual dysfunction from the medications. It can be due to the severity of the depressive symptoms in patients struggling with treatment-resistant depression [5]. The guidelines recommend the selection of a different class of antidepressant with a different mode of action after the failure of antidepressant treatment with SSRIs or selective serotonin-norepinephrine reuptake inhibitor (SNRI). This recommendation is based on the fact that a medication with a different mechanism of action may have a better chance of success than the traditional antidepressants [3]. This recommendation is based on the heterogeneity of MDD in etiology, underlying the neurobiological mechanism, pathogenesis, course, and prognosis of illness. The serotonin and norepinephrine reuptake inhibitors have different potency of action at their respective receptors, resulting in distinctive clinical effects. With the distinctive treatment effect, the action of antidepressant medications, for example, SSRIs are restricted due to autoregulatory feedback mechanisms. To counteract the autoregulatory feedback, different methodologies are considered such as the addition of $5-\mathrm{HT}_{1 \mathrm{~A}}, 5-\mathrm{HT}_{1 \mathrm{~B}}$, and partial 5-

$\mathrm{HT}_{1 \mathrm{~A}}$ receptor agonism to SSRIs [6].

There are several newer treatment options including desvenlafaxine, vortioxetine, vilazodone, and levomilnacipran with antidepressant actions through different neurochemical actions. This review article educates the clinicians about the clinical factors including the mechanism of action, pharmacokinetics, clinical efficacy, and safety and tolerability. The authors also provide a summary of evidence-based studies regarding the newer antidepressants. This review articles explored the randomized controlled trials (RCTs), open-label trials, and case reports.

\section{Review}

\section{Review and search strategy}

This article reviews the mechanism of action, pharmacokinetics, clinical efficacy, and safety and tolerability of desvenlafaxine, vortioxetine, vilazodone, and levomilnacipran extended release (ER). In April 2018, two electronic databases were systematically searched for relevant publications, including PubMed and Scopus, using the following search terms: (depression) AND (psychopharmacology OR desvenlafaxine OR levomilnacipran OR vortioxetine OR vilazodone). The manual search of references and relevant articles for included studies was also performed. Search results from these databases were imported to Endnote $\times 7$ (Thompson Reuter, CA, USA) to remove any duplicates. Two independent reviewers performed title and abstract screening (when available) followed by the full-text screening of 1674 included articles by selecting case reports, case series, open-label trials, and RCTs. In the case of disagreement, the consensus was reached by discussion among reviewers or guidance from a senior reviewer (SN). The abstract-only articles, conference papers without original data, review articles, theses, posters, book chapters, editorials, letters, commentaries were excluded. No restrictions on language, country, publication year, age, gender, or ethnicity of patients were applied. After the full-text screening, 41 studies were included in this review articles.

\section{Desvenlafaxine}

Desvenlafaxine, an active metabolite of venlafaxine, is an SNRI approved by the Food and Drug Administration (FDA) for the treatment of MDD in adults in 2009. It is administered as 
desvenlafaxine succinate [7].

\section{Mechanism of action}

Desvenlafaxine causes selective reuptake inhibition at the serotonin (5-HT) and norepinephrine (NE) transporters, resulting in an increased extracellular concentration of 5-HT and NE. The higher affinity for 5-HT transporters is observed compared to the NE transporters (approximately 10-fold) with a much weaker affinity for dopamine transporters (DATs). However, there are no functional implications on dopamine levels with the concentrations required to inhibit 5-HT and NE transporters for the antidepressant effect. Desvenlafaxine also affects hypothalamus which is an important regulator of biological functions like mood, sleep cycle, stress response, sexual behaviors, temperature, and pain sensations [8]. It lacks significant affinity for numerous receptors, including muscarinic cholinergic, histaminergic, and $\alpha 1$-adrenergic receptors, and monoamine oxidase (MAO) receptors [7], possibly reducing the risk of undesired side effects related to these receptor sites.

\section{Dosage}

Desvenlafaxine is available in 50 and $100 \mathrm{mg}$ tablets. The recommended dose for desvenlafaxine is $50 \mathrm{mg} /$ day. In a patient with hepatic impairment, the dose above $100 \mathrm{mg} /$ day is not recommended. In patients with moderate and severe renal impairment, the maximum dose was $50 \mathrm{mg} /$ day and $50 \mathrm{mg}$ every other day, respectively [7].

\section{Pharmacokinetics}

The bioavailability of desvenlafaxine is $80 \%$ after an oral administration and peak plasma concentration (Tmax) is seven and half hours after oral administration. It can be taken without meals as food does not appear to have a clinically significant difference. It is metabolized by conjugation and to a minor extent by oxidation through CYP3A4 [7]. Findling et. al reported a linear increase in Cmax and Area Under Curve (AUC) with an increase in the dose of desvenlafaxine in children and adolescents [9].

\section{Clinical use}

The efficacy of desvenlafaxine for MDD has been established in several RCTs and open-label studies among adults [9-17]. It improves the quality of life, as measured by an improvement in mood, social relationships, daily functioning, leisure activities, economic status, and physical mobility [13]. In patients with liver pathology, it alleviated the symptoms of depression [18-19]. In a case report of a patient with social phobia, the dose of $100 \mathrm{mg} /$ day resulted in the remission of the symptoms [19]. An open-label trial also evaluated the efficacy of desvenlafaxine among children (aged 7-11 years) and adolescents (aged 12-17 years). The dose range of 50-200 mg was used in children (10-100 mg/day) and adolescents (25-200 mg/day) with a favorable response. The higher doses were associated with an increased incidence of treatment-emergent side effects [20]. Table 1 provides a summary of the characteristics of these trials including sample size, duration, doses, and age ranges of the participants. Table 2 summarizes the clinical outcomes for these studies.

\begin{tabular}{|c|c|c|c|c|c|}
\hline Studies & Design & Groups (n) & $\begin{array}{l}\text { Duration } \\
\text { (weeks) }\end{array}$ & $\begin{array}{l}\text { Age } \\
\text { (years) }\end{array}$ & $\begin{array}{l}\text { Dose range } \\
\text { (mg) }\end{array}$ \\
\hline & & $\begin{array}{l}\text { Desvenlataxine } 100 \\
\mathrm{mg} / \text { day=114 }\end{array}$ & & & \\
\hline & & Desvenlafaxine 200 & & & \\
\hline
\end{tabular}




\section{Cureus}

DeMartinis NA, et al., 2007 [11]

Septien-Velez L, et al., 2007 [14]

Liebowitz MR, et al., 2008

[16]

Feiger AD, et al., 2009 [6]

Dunlop BW, et al., 2011 [12]

Clayton AD, et al., 2013 [10]

Ferguson JM, et al., 2012 [13]

Findling RL, et al., 2014 [20]

Findling RL, et al., 2016 [9] OL 59

Fábregas B, et al., 2014 [18] CR 2

Feinberg SS, et al., 2010[19] CR 1 $\mathrm{mg} / \mathrm{day}=116$

8

$18-75$

$100-400$

Desvenlafaxine 400

$\mathrm{mg} /$ day $=113$

Placebo $=118$

Desvenlafaxine $200 \mathrm{mg}=124$

$\mathrm{RCT}$ Desvenlafaxine $100 \mathrm{mg}=1258$

18-75 200-400

Placebo $=126$

Desvenlafaxine 50 mg=166

RCT Desvenlafaxine $100 \mathrm{mg}=148 \quad 8$

$>18$

$50-100$

Placebo $=161$

Desvenlafaxine $50 \mathrm{mg}=158$

$\mathrm{RCT} \quad$ Desvenlafaxine $100 \mathrm{mg}=157 \quad 8$

$>18$

$50-100$

Placebo $=159$

Desvenlafaxine $=117$

Placebo $=118$

8

$>18$

$200-400$

Desvenlafaxine $=285$

Placebo $=142$

12

18-75

50

Desvenlafaxine $=217$

Placebo $=217$

8

40-70

50

OL $\quad 104$

12 months

18-75 200-400

Desvenlafaxine $=40$

8 weeks (Fix)

7-17

$20(\mathrm{C})$ and $20(\mathrm{~A})$

6 months (Flex)

$10-100(C)$

25-200 (A)

8

7-17

10-200

8

$45,49 \quad 100$

12 100

\section{TABLE 1: Summary of demographic characteristics, dose ranges, and duration of}

\section{studies of Desvenlafaxine}

A: Adolescent, C: Children, Case Report: CR, Fix: fixed dose, Flex: Flexible dose, OLT: Open-label trial, RCT: Randomized controlled trial 


\section{Cureus}

\section{Studies}

DeMartinis NA, et al., 2007 [11]

Septien-Velez L, et al., 2007 [14]

Boyer P, et al., 2015 [15]

Liebowitz MR, et al., 2008 [16]

Feiger AD, et al., 2009

[6]

Dunlop BW, et al., 2011

[12]

Clayton AD, et al., 2013

[10]

Ferguson JM, et al., 2012 [13]

Findling RL, et al., 2014

[20]

Findling RL, et al., 2016

[9]

Fábregas B, et al., 2014 [18]

Feinberg SS, et al., 2010 [19]

\section{Clinical outcomes}

Des 100 and $400 \mathrm{mg}$ helped with depression, $200 \mathrm{mg}$ was not statistically significant compared to placebo.

Des 200 and 400 mg was effective compared to placebo for depressive symptoms and global functioning.

Des 50 and $100 \mathrm{mg}$ was effective compared to placebo for depressive symptoms and global functioning.

Des 50 and $100 \mathrm{mg}$ was effective for depression, $100 \mathrm{mg}$ was not statistically significant compared to placebo.

Des 200 and $400 \mathrm{mg}$ was effective compared to placebo for depression but failed to reach statistical significance.

Response and remission rates were $60 \%$ and $42 \%$ with des compared to $42 \%$ and $30 \%$ with placebo.

Des helped with depression and functional status among perimenopausal and postmenopausal women.

High dose des was found to be safe and effective for MDD for up to a year.

Des was effective for depression in short-term and long-term duration.

Des was safe and well-tolerated in youth. The AUC was found to be linear with dosage.

Des helped with depression with full remission after IFN in one patient. In second patient, there was only minor improvement.

Des $100 \mathrm{mg}$ was effective for social phobia in a patient with Gilbert syndrome.

\section{TABLE 2: Summary of clinical outcomes of studies of Desvenlafaxine}

AUC: Area Under Curve, Des: Desvenlafaxine, IFN: Interferon, MDD: Major Depressive Disorder

\section{Safety and tolerability}

The treatment-emergent adverse effects (AEs) are dose-related with desvenlafaxine and are the most common reason to discontinue treatment. Serious AEs were reported in $0.9 \%$ of patients taking desvenlafaxine compared to $0.4 \%$ taking a placebo. An analysis of AEs reported completed suicide in one, suicidal attempt in three, and suicidal ideations in five patients taking desvenlafaxine. However, the difference in suicidal behaviors was not statistically significant among desvenlafaxine and placebo groups. The most common AEs are nausea, headache, dizziness, insomnia, and dry mouth. Other side effects included fatigue, hyperhidrosis, tremors, blurred vision, sedation, increased anxiety, mydriasis, dyspepsia, affective lability, muscle spasms, and taste perversion. In patients taking desvenlafaxine, vital 
signs, laboratory results, and electrocardiogram (EKG) findings were clinically insignificant. Small increases in pulse and blood pressures were observed possibly due to noradrenergic effects of desvenlafaxine but they were clinically insignificant. Desvenlafaxine was associated with a lower risk of QTc prolongation compared to placebo. Dose-dependent lipid abnormalities were clinically significant in $1 \%$ of patients [21]. Abrupt discontinuation or dose reduction were associated with dizziness, nausea, headache, irritability, insomnia, diarrhea, anxiety, fatigue, abnormal dreams, and hyperhidrosis. The discontinuation rates are higher among patients taking it for a longer duration, needing a gradual taper [7].

\section{Pregnancy}

In pregnant rats and rabbits, desvenlafaxine causes a decrease in fetal weight with no evidence of teratogenicity. However, there are not adequate studies in pregnant women [7].

\section{Vortioxetine}

Vortioxetine was approved for the treatment of MDD in 2013 by the FDA. It contains the beta polymorph of vortioxetine hydrobromide and administered as an immediate-release tablet [22].

\section{Mechanism of action}

Vortioxetine exerts its therapeutic effects through multimodal activity with a modulation of the 5 -HT receptors and an inhibition of the 5-HT transporters [22]. The antidepressant effect of the vortioxetine is mediated through its antagonist effect on the $5-\mathrm{HT}_{3}, 5-\mathrm{HT}_{7}$, and $5-\mathrm{HT}_{1 \mathrm{D}}$ receptors, partial agonist activity on the 5-HT1B receptor, agonist effect on the 5-HT1A receptor, and inhibition of the 5-HT transporter. Beside the modulatory effect on the 5-HT receptors and transporter, it also enhances the extracellular concentration of various neurotransmitters such as dopamine, histamine, noradrenaline, and acetylcholine [23].

At the standard dose of SSRI and SNRI medications, 80\% occupancy of the serotonin transporter (SERT) is achieved, however $5 \mathrm{mg}$ of vortioxetine occupies about $40 \%$ of the SERT suggesting the role of other pharmacological actions. In the healthy participants, the serotonin occupancy of vortioxetine was $\approx 50 \%$ at $5 \mathrm{mg}, 65 \%$ at $10 \mathrm{mg}$, and $>80 \%$ at $20 \mathrm{mg}$. The series of inhibitory feedback in response to prolonged SERT blockade decreases the extracellular 5-HT concentration and also attenuates the activation of $5-\mathrm{HT}_{1 \mathrm{~A}}$ and $5-\mathrm{HT}_{1 \mathrm{~B}}$ auto-receptors of the serotonergic system. The partial agonist activity of vortioxetine counteracts the 5-HT1B autoreceptor activity and in turn, increases the serotonin synthesis and release. The full agonist activity of vortioxetine on the $5 \mathrm{HT}_{1 \mathrm{~A}}$ receptor normalizes the serotonin release through the likely mechanism of rapid desensitization of $5 \mathrm{HT}_{1 \mathrm{~A}}$ auto-receptors. The antagonist effect on the $5-\mathrm{HT}_{3}$ receptor inhibits the GABA-mediated inhibition of the interneurons, thereby increasing the extracellular serotonin concentration. Similarly, the blockade of $5-\mathrm{HT}_{7}$ and $5 \mathrm{HT}_{1 \mathrm{D}}$ receptors has shown the effect of antidepressants in an animal study. The 5 -HT system has a favorable impact on mood, affect, and cognition. Vortioxetine modulates the essential neurotransmitters which are involved in cognitive regulation such as glutamate, acetylcholine, histamine, dopamine, and noradrenaline [24].

\section{Dosage}

Vortioxetine is available as 5, 10, and $20 \mathrm{mg}$ tablets. It can be started at $10 \mathrm{mg}$ once daily and the dose can be increased to $20 \mathrm{mg}$ based on the tolerability and clinical response [22].

\section{Pharmacokinetics}




\section{Cureus}

In vivo, vortioxetine shows a linear, and dose-proportional relationship, i.e. c-max, and AUC increases linearly with dose (2.5-60 mg). It has moderate oral bioavailability that is independent of food intake. Vortioxetine has an extensive volume of distribution as the plasma protein binding is $80-90 \%$. The study also revealed a significant separation of vortioxetine from placebo over the graph at the higher dose $(20 \mathrm{mg})$ suggesting that a higher dose may potentially yield a better outcome. It takes 3-16 hours to attain maximum plasma concentration after dosing, and with multiple doses, the terminal half-life is approximately 60-70 hours.

Vortioxetine is metabolized extensively in the liver and is the substrate for numerous CYP450 isoforms, primarily CYP2D6. In the liver, the CYP450 isoforms extensively metabolize the vortioxetine through oxidation and subsequent glucuronic acid conjugation to a pharmacologically inactive carboxylic acid metabolite. The medication itself does not have an inhibitory or excitatory effect on CYP1A2, CYP2C9, CYP2C19, CYP2D6 or CYP3A4 [24-25]. However, the increased risk of bleeding is explained by inhibition of serotonin uptake by platelets, an increase in gastric acid secretion, and modulation of the CYP450 metabolism [26].

\section{Clinical use}

The efficacy of vortioxetine for MDD was established in nine RCTs in adults at a dose range of 5-20 $\mathrm{mg}$ [3, 25, 27-33]. The doses of 5-20 $\mathrm{mg}$ were found to be in effective range with a lack of effectiveness with lower doses of 2.5-5 $\mathrm{mg}$ [24]. The maximum dose of vortioxetine $20 \mathrm{mg}$ exhibits a greater clinical response compared to the lower doses for vortioxetine [27-30]. This dose of $20 \mathrm{mg}$ was also associated with a higher risk of side effects. The improvement in global functioning [23,25,28-29,31-33], quality of life [28-29,32], and anxiety [23,25,28-29, 31-32,34] was also reported with vortioxetine. In an open-label trial of 52 weeks, it was effective in relapse prevention of depressive symptoms [34]. Table 3 provides a summary of the characteristics of these trials including sample size, duration, doses, and age ranges of the participants. Table 4 summarizes the clinical outcomes for these studies.

\begin{tabular}{|c|c|c|c|c|c|}
\hline Studies & Design & Groups (n) & $\begin{array}{l}\text { Duration } \\
\text { (weeks) }\end{array}$ & Age (years) & Dose range $(\mathrm{mg})$ \\
\hline \multirow{2}{*}{ Alvarez E, et al., 2012 [25] } & \multirow{2}{*}{ RCT } & $\begin{array}{l}\text { Lu } 5 \text { mg=109 } \\
\text { Lu } 10 \text { mg=101 }\end{array}$ & \multirow{2}{*}{6} & \multirow{2}{*}{$18-65$} & $\mathrm{Lu}=5,10$ \\
\hline & & $\begin{array}{l}\text { Placebo=105 } \\
\text { Venlafaxine } \\
X R=114\end{array}$ & & & Venlafaxine =225 \\
\hline \multirow[b]{2}{*}{ Baldwin DS, et al., 2012 [23] } & \multirow[b]{2}{*}{ RCT } & $\begin{array}{l}\text { Lu } 2.5 \text { mg=155 } \\
\text { Lu } 5 \text { mg=159 }\end{array}$ & \multirow[b]{2}{*}{8} & \multirow[b]{2}{*}{$18-75$} & $\mathrm{Lu}=2.5,5,10$ \\
\hline & & $\begin{array}{l}\text { Lu } 10 \text { mg=153 } \\
\text { Duloxetine=157 } \\
\text { Placebo=152 }\end{array}$ & & & Duloxetine $=60$ \\
\hline \multirow[b]{2}{*}{ Boulenger JP, et al., 2012 [30] } & Phase1=OLT & OLT=639 & $\begin{array}{l}\text { OLT=12 } \\
\text { weeks }\end{array}$ & \multirow[b]{2}{*}{$18-75$} & \multirow[b]{2}{*}{5,10} \\
\hline & $\begin{array}{l}\text { Phase } \\
2=\mathrm{RCT}\end{array}$ & RCT: Lu=204 & & & \\
\hline
\end{tabular}




\section{Cureus}

\begin{tabular}{|c|c|c|c|c|c|}
\hline & & Placebo=192 & $\begin{array}{l}\mathrm{RCT}=26-64 \\
\text { weeks }\end{array}$ & & \\
\hline Jain R, et al., 2013 [31] & RCT & $\begin{array}{l}\text { Vortioxetine } 5 \\
\text { mg=300 } \\
\text { Placebo=300 }\end{array}$ & 6 & $18-75$ & 5 \\
\hline $\begin{array}{l}\text { Mahableshwarkar AR, et al., } \\
2013 \text { [33] }\end{array}$ & RCT & $\begin{array}{l}\text { Vortioxetine } 2.5 \\
\text { mg=153 } \\
\text { Vortioxetine } 5 \\
\text { mg=153 } \\
\text { Placebo=300 }\end{array}$ & 8 & $18-75$ & $2.5,5$ \\
\hline \multirow[t]{2}{*}{ Boulenger JP, et al., 2014 [27] } & \multirow[t]{2}{*}{$\mathrm{RCT}$} & $\begin{array}{l}\text { Vortioxetine } 15 \\
\text { mg=152 } \\
\text { Vortioxetine } 20 \\
\text { mg=151 }\end{array}$ & \multirow[t]{2}{*}{8} & \multirow[t]{2}{*}{$18-75$} & Vortioxetine $=15,20$ \\
\hline & & $\begin{array}{l}\text { Duloxetine=147 } \\
\text { Placebo=158 }\end{array}$ & & & Duloxetine=60 \\
\hline $\begin{array}{l}\text { Montgomery SA, et al., } 2014 \\
\text { [3] }\end{array}$ & RCT & $\begin{array}{l}\text { Vortioxetine } 5 \\
\mathrm{mg}=255 \\
\text { Agomelatine }=246\end{array}$ & 12 & $18-75$ & $10-20$ \\
\hline Chen G, et al., 2015 [26] & RCT & $\begin{array}{l}\text { Aspirin and } \\
\text { vortioxetine } \\
\text { Warfarn and } \\
\text { vortioxetine }\end{array}$ & 20 days & $18-45$ & Venlafaxine $=10$ \\
\hline Jacobsen PL, et al., 2015 [28] & RCT & $\begin{array}{l}\text { Vortioxetine } 10 \\
\text { mg=155 } \\
\text { Vortioxetine } 20 \\
\text { mg=150 } \\
\text { Placebo=157 }\end{array}$ & 8 & $18-75$ & $10-20$ \\
\hline \multirow[t]{2}{*}{$\begin{array}{l}\text { Mahableshwarkar AR, et al., } \\
2015 \text { [29] }\end{array}$} & \multirow[t]{2}{*}{$\mathrm{RCT}$} & $\begin{array}{l}\text { Vortioxetine } 15 \\
\mathrm{mg}=147\end{array}$ & \multirow[t]{2}{*}{6} & \multirow[t]{2}{*}{$18-75$} & Vortioxetine $=15,20$ \\
\hline & & $\begin{array}{l}\text { Duloxetine=152 } \\
\text { Placebo=161 }\end{array}$ & & & Duloxetine=60 \\
\hline Alam MY, et al., 2014 [34] & OLT & 310 & 52 & $\begin{array}{l}\text { Mean } \\
\text { age }=45.5\end{array}$ & $2.5-10$ \\
\hline
\end{tabular}




\section{Cureus}

\section{TABLE 3: Summary of demographic characteristics, dose ranges, and duration of studies of Vortioxetine}

Lu:LuA21004, No.: number, OLT: Open-label trial, RCT: Randomized controlled trial, XR: Extended release

Studies

Alvarez E, et al., 2012[25]

Baldwin DS, et al., $2012[23]$

Boulenger JP, et al., 2012 [30]

Jain $\mathrm{R}$, et al., 2013 [31]

Mahableshwarkar AR, et al., 2013 [33]

Boulenger JP, et al., 2014 [27]

Montgomery SA, et al., 2014 [3]

Chen G, et al., 2015 [26]

Jacobsen PL, et al., 2015 [28]

Mahableshwarkar AR, et al., 2015 [29]

Alam MY, et al., 2014[34]

\section{Clinical outcomes}

Lu helped with depression, anxiety, and global functioning compared to placebo.

Lu and duloxetine helped with depression but it failed to reach statistical significance compared to placebo.

Lu helped with relapse of depression compared to placebo.

The was no significant difference in symptoms of depression at week 6 compared to placebo.

Vortioxetine 2.5 and $5 \mathrm{mg}$ helped with depression compared to placebo but it was not statistically significant.

Lu and duloxetine resulted in an improvement in depression and anxiety compared to placebo.

Vortioxetine was significantly superior to placebo for depression, anxiety and global functioning.

Vortioxetine had no effect on the steady-state pharmacokinetics of aspirin and warfarin.

Vortioxetine $20 \mathrm{mg}$ was significantly superior to placebo for depression compared to placebo.

Vortioxetine $20 \mathrm{mg}$ helped with depression and anxiety.

Participants taking vortioxetine experienced improvement in depression and anxiety symptoms.

\section{TABLE 4: Summary of clinical outcomes of studies of Vortioxetine}

Lu=LuA21004

\section{Safety and tolerability}

The side effect profile of vortioxetine has an indirect effect on the management of depressive symptoms. These side effects result in the discontinuation of vortioxetine (3-11\%) compared to placebo $1-8 \%[23,27]$. In two studies of vortioxetine, nausea was the most frequent $\mathrm{AE}$ with an incidence reported as $10 \%$ [28-29].

The most common AEs reported in at least $5 \%$ of patients in order were nausea, headache, diarrhea, and dry mouth [28]. Sexual dysfunction is not an uncommon side effect of medication 
with serotonin reuptake inhibitor and is one of the reasons for treatment discontinuation and noncompliance [29]. Interestingly, the side effects including abnormal orgasm, ejaculation disorder, decreased libido, erectile dysfunction were reported to be higher with a low dose of vortioxetine $2.5 \mathrm{mg}$ compared to $5 \mathrm{mg}$ dose [33]. The gender has a variable effect on the incidence of AEs in vortioxetine with men at a higher risk compared to women [23].

The incidence of hemorrhage in a short-term clinical study with a dose range of $10-20 \mathrm{mg} / \mathrm{day}$ was lower, and it was similar between vortioxetine (1.7\%) and placebo (1.2\%) participants [26]. In a study of vortioxetine $15 \mathrm{mg}$, two serious AEs (stress fracture and suicidal ideation) were reported [29]. There was no clinically significant relevance to suicidal ideation and behavior as measured by the Columbia Suicide Severity Rating Scale [27,29,33]. There was no change in vital signs, laboratory test results, weight, or EKG parameters for participants [23,25,29-30]. Sudden discontinuation of vortioxetine after two weeks of treatment showed no clinically significant withdrawal effect versus placebo [28-29].

\section{Pregnancy}

In a pregnant patient, vortioxetine $5 \mathrm{mg}$ was discontinued after one month. Delivery of the healthy baby (3800 mg in weight) was reported [23]. It can cause decreased fetal weight and delayed ossification in animal studies [22].

\section{Vilazodone}

Vilazodone, an SSRI and a partial 5- $\mathrm{HT}_{1 \mathrm{~A}}$ receptor agonist, was approved for the treatment of MDD in adults by FDA in 2011 [35].

\section{Mechanism of action}

Vilazodone enhances serotonergic activity by selective inhibition of serotonin reuptake through the blockade of SERT. This effect is further intensified because of partial agonist activity at $5-\mathrm{HT}_{1 \mathrm{~A}}$ receptors [35].

\section{Dosage}

Vilazodone tablets are available in 10,20, and $40 \mathrm{mg}$ strengths. The recommended dose range is 20-40 mg once daily. Vilazodone should be titrated, starting with an initial dosage of $10 \mathrm{mg}$ once daily for seven days which can be titrated to $20 \mathrm{mg}$ once daily. The dose can be increased to $40 \mathrm{mg}$ once daily after seven days. The administration of Vilazodone without food affects the systemic bioavailability and diminished clinical effectiveness due to inadequate drug levels [35].

\section{Pharmacokinetics}

Vilazodone has a dose-proportional pharmacokinetic activity (5-80 mg). It reaches peak concentration in four to five hours after administration and has an elimination half-life of 25 hours. It is widely distributed and is $96-99 \%$ protein bound. Vilazodone is extensively metabolized through both cytochrome P450 (CYP) pathways (major: CYP3A4, minor: CYP2C19 and CYP2D6), with little to unchanged drug recovered in the urine (1\%) and feces (2\%) [35].

A sequence of open-label studies conducted by Boepally and colleagues identified the effect of CYP3A4 inhibition or induction on the pharmacokinetics of vilazodone. The average AUC of vilazodone exposure increased from $42-51 \%$ if given with ketoconazole, however, the coadministration of vilazodone and carbamazepine XR, a CYP3A4 inducer, decreased mean steady-state vilazodone exposure by $45 \%$. The results suggest that up to a $50 \%$ decrease of vilazodone dosage should be considered when it is given in combination with strong CYP3A4 
inhibitors; conversely, increasing the vilazodone dosage up to a maximum of $80 \mathrm{mg} / \mathrm{day}$ should be considered when it is given in combination with strong CYP3A4 inducers [36].

\section{Clinical use}

The efficacy of vilazodone in the treatment of MDD was established in two RCTs [37-38]. The participants in these studies reported an improvement in depressive symptomatology including depression-related anxiety symptoms and overall disease severity. These findings from these pivotal studies were replicated in another study with randomization to $40 \mathrm{mg} /$ day of vilazodone or placebo for eight weeks of a double-blind trial [39]. Vilazodone resulted in significant improvements in their symptoms of depression and anxiety compared to placebo from the baseline to endpoint. Vilazodone $40 \mathrm{mg}$ is noted to be an effective treatment choice in depression and anxiety with a resultant decrease in scores on the corresponding scales. In a study, 79 adults with MDD were enrolled in an open-label study of citalopram $20 \mathrm{mg} /$ day for six weeks [40]. The symptomatic patients after a six-week trial of citalopram $20 \mathrm{mg}$ were randomly assigned to either higher dose of citalopram $40 \mathrm{mg} /$ day or to a vilazodone $40 \mathrm{mg} /$ day. Both groups showed decreases in all outcome measures, but there were no significant differences between groups. Initial non-responders to a low dose of citalopram seem equally likely to respond to a higher dose of citalopram or to vilazodone. These findings were replicated in another study comparing the efficacy of citalopram and vilazodone [2]. Table 5 provides a summary of the characteristics of these trials including sample size, duration, doses, and age ranges of the participants. Table 6 summarizes clinical outcomes for these studies. 


\section{Cureus}

\begin{tabular}{|c|c|c|c|c|c|}
\hline Studies & Design & Groups (n) & $\begin{array}{l}\text { Duration } \\
\text { (weeks) }\end{array}$ & $\begin{array}{l}\text { Age } \\
\text { (years) }\end{array}$ & $\begin{array}{l}\text { Dose range } \\
\text { (mg) }\end{array}$ \\
\hline \multirow{2}{*}{$\begin{array}{l}\text { Rickels K, et al., } 2009 \\
\text { [37] }\end{array}$} & \multirow{2}{*}{ RCT } & Vilazodone=198 & \multirow{2}{*}{8} & \multirow{2}{*}{$18-65$} & \multirow{2}{*}{40} \\
\hline & & Placebo=199 & & & \\
\hline Khan A, et al., 2011 [38] & RCT & 481 & 8 & $18-70$ & 40 \\
\hline \multirow{2}{*}{$\begin{array}{l}\text { Boinpally R, et al., } 2014 \\
\text { [36] }\end{array}$} & \multirow{2}{*}{ RCT } & $\begin{array}{l}\text { Vilazodone and } \\
\text { Ketoconazole }=37\end{array}$ & \multirow{2}{*}{8} & \multirow{2}{*}{$18-60$} & $5-10$ \\
\hline & & $\begin{array}{l}\text { Vilazodone and } \\
\text { Carbamazepine }=30\end{array}$ & & & 40 \\
\hline \multirow{2}{*}{ Croft HA, et al., 2015 [39] } & \multirow{2}{*}{ RCT } & Vilazodone $=253$ & \multirow{2}{*}{8} & \multirow{2}{*}{$18-70$} & \multirow{3}{*}{50} \\
\hline & & Placebo=252 & & & \\
\hline \multirow{4}{*}{$\begin{array}{l}\text { Matthews M, et al., } 2015 \\
\text { [2] }\end{array}$} & \multirow{4}{*}{ RCT } & Vilazodone 20 mg=292 & Single dose & $32-76$ & \\
\hline & & Vilazodone 40 mg=291 & \multirow{3}{*}{10} & \multirow{3}{*}{$18-70$} & \multirow{3}{*}{$20-40$} \\
\hline & & Citalopram 40 mg=289 & & & \\
\hline & & Placebo=290 & & & \\
\hline \multirow{3}{*}{ Rele S, et al., 2015 [41] } & \multirow{3}{*}{ RCT } & Vilazodone 10 mg=20 & \multirow{3}{*}{8} & \multirow{3}{*}{$18-65$} & \multirow{3}{*}{$10-40$} \\
\hline & & Vilazodone 20 mg=20 & & & \\
\hline & & Vilazodone $40 \mathrm{mg}=20$ & & & \\
\hline \multirow{3}{*}{ Grant JE, et al., 2017 [40] } & \multirow{3}{*}{ RCT } & Study 1: Citalopram 20 mg=79 & \multirow{3}{*}{12} & \multirow{3}{*}{$18-60$} & \multirow{3}{*}{40} \\
\hline & & Study 2: Citalopram 40 mg=23 & & & \\
\hline & & Study 2: Vilazodone $40 \mathrm{mg}=19$ & & & \\
\hline
\end{tabular}

TABLE 5: Summary of demographic characteristics, dose ranges, and duration of studies of Vilazodone

DB: Double-blinded, RCT: Randomized controlled trial 


\section{Cureus}

\begin{tabular}{|c|c|}
\hline Studies & Clinical outcomes \\
\hline $\begin{array}{l}\text { Rickels K, et al., } \\
2009 \text { [37] }\end{array}$ & Vilazodone-treated patient had higher response compared to placebo with improvement. \\
\hline $\begin{array}{l}\text { Khan A, et al., } 2011 \\
\text { [38] }\end{array}$ & Vilazodone resulted in significant improvement in depressive symptoms compared to placebo \\
\hline \multirow{2}{*}{$\begin{array}{l}\text { Boinpally R, et al., } \\
2014 \text { [36] }\end{array}$} & $50 \%$ dose reduction of vilazodone is needed with strong CYP3A4 inhibitors. \\
\hline & Vilazodone dosage up to a maximum of $80 \mathrm{mg}$ with strong CYP3A4 inducers. \\
\hline $\begin{array}{l}\text { Croft HA, et al., } 2015 \\
\text { [39] }\end{array}$ & Statistically significant outcomes were found for vilazodone 40 mg/day versus placebo. \\
\hline $\begin{array}{l}\text { Matthews M, et al., } \\
2015 \text { [2] }\end{array}$ & $\begin{array}{l}\text { Vilazodone } 20 / 40 \mathrm{mg} \text { was equal in efficacy and tolerability as citalopram } 40 \mathrm{mg} \text { compared to } \\
\text { placebo. }\end{array}$ \\
\hline $\begin{array}{l}\text { Rele S, et al., } 2015 \\
{[41]}\end{array}$ & $\begin{array}{l}\text { There was a significant improvement in depression measures from baseline to the end of the } \\
\text { study. }\end{array}$ \\
\hline $\begin{array}{l}\text { Grant JE, et al., } \\
2017[40]\end{array}$ & $\begin{array}{l}\text { Initial non-responders to a low dose of citalopram seems equally likely to respond to a higher dose } \\
\text { of citalopram or to vilazodone. }\end{array}$ \\
\hline
\end{tabular}

\section{TABLE 6: Summary of clinical outcomes of studies of Vilazodone}

\section{Safety and tolerability}

The discontinuation rates due to AEs were higher with vilazodone than placebo [41]. The most common AEs of vilazodone were vomiting, nausea, diarrhea, insomnia, somnolence, dizziness, and dry mouth [35]. There were no noticeable changes in vital signs, in laboratory test results, weight, or EKG parameters among different treatment groups [35]. There was no clinically significant relevance to suicidal ideations and behaviors in short-term studies [2].

In a study, the safety of vilazodone was compared to placebo, and citalopram was included as an active control. Both vilazodone and citalopram were generally well tolerated [39]. The most commonly reported AEs leading to discontinuation were nausea (placebo, $n=1$; vilazodone 20 $\mathrm{mg} /$ day, $\mathrm{n}=6$; vilazodone $40 \mathrm{mg} /$ day, $\mathrm{n}=3$, citalopram, $\mathrm{n}=4$ ). The incidence of vomiting and somnolence was greater in the vilazodone $40 \mathrm{mg} /$ day group compared to the vilazodone 20 $\mathrm{mg}$ /day group. Overall, the incidence of AEs related to sexual functioning was higher in the active treatment groups relative to placebo and they were more frequent in the citalopram group. No patient in the vilazodone groups withdrew due to sexual side effects. Abrupt discontinuation or dose reduction lead to dysphoric mood, irritability, agitation, dizziness, sensory disturbances (e.g., paresthesia, such as electric shock sensations), anxiety, confusion, headache, lethargy, emotional lability, insomnia, hypomania, tinnitus, and seizures [35].

\section{Pregnancy}

Vilazodone is reported to cause developmental toxicity in rats but teratogenicity has not been reported in animal studies. There is a lack of adequate and well-controlled studies of vilazodone in pregnant women, needing a careful analysis of potential benefits and risks of treatment [35]. 


\section{Levomilnacipran ER}

Levomilnacipran ER, 1S, 2R- milnacipran, is an SNRI approved by the FDA for the treatment of MDD in adults [42].

\section{Mechanism of action}

All SNRIs inhibit the reuptake of 5-HT and NE with a difference in their potencies for the respective transporters, resulting in clinical implications [43]. Levomilnacipran ER is a relatively more active enantiomer of racemic milnacipran. It has two-folds higher potency for norepinephrine compared to serotonin reuptake inhibition and preferentially inhibits norepinephrine reuptake compared to duloxetine, venlafaxine, and desvenlafaxine [44]. It lacks effect on other receptors, ion channels or transporters tested in vitro, including serotonergic $\left(5 \mathrm{HT}_{1-7}\right), \alpha$ - and $\beta$ - adrenergic, muscarinic, or histaminergic receptors and $\mathrm{Ca} 2+, \mathrm{Na}+, \mathrm{K}+$ or $\mathrm{Cl}-$ channels [45].

\section{Dosage}

Levomilnacipran is an ER formulation, allowing once-daily dosing. The recommended dose range for levomilnacipran is $40-120 \mathrm{mg} /$ day. The starting dose is $20 \mathrm{mg} /$ day and then it can be increased to $40 \mathrm{mg} /$ day after two days. The dose can be further titrated in increments of $40 \mathrm{mg}$ every two or more days [45].

\section{Pharmacokinetics}

Levomilnacipran ER is well absorbed after oral administration with a bioavailability of $92 \%$. The mean time to achieve peak plasma concentration is six to eight hours after oral administration and has a protein binding of $22 \%$. Food does not affect the oral bioavailability of levomilnacipran. It is metabolized by CYP3A4 with minor involvement of other pathways in the CYP450 system [45]. It has an elimination half-life of around 12 hours with a prolongation in patients with renal impairment [46].

\section{Clinical use}

The efficacy of levomilnacipran for MDD and global functioning is established in five RCTs among adults at doses of 40-120 mg/day [44,47-50]. In an RCT by Gommoll et. al, there was an improvement in depressive symptoms, but it didn't reach statistical significance [50]. Asnis et al. (2013) suggested a superior response for $80 \mathrm{mg}$ and $120 \mathrm{mg}$ doses compared to $40 \mathrm{mg}$ [47]. Table 7 provides a summary of the characteristics of these trials including sample size, duration, doses, and age ranges of the participants. Table 8 summarizes the clinical outcomes and findings from these studies. 


\section{Cureus}

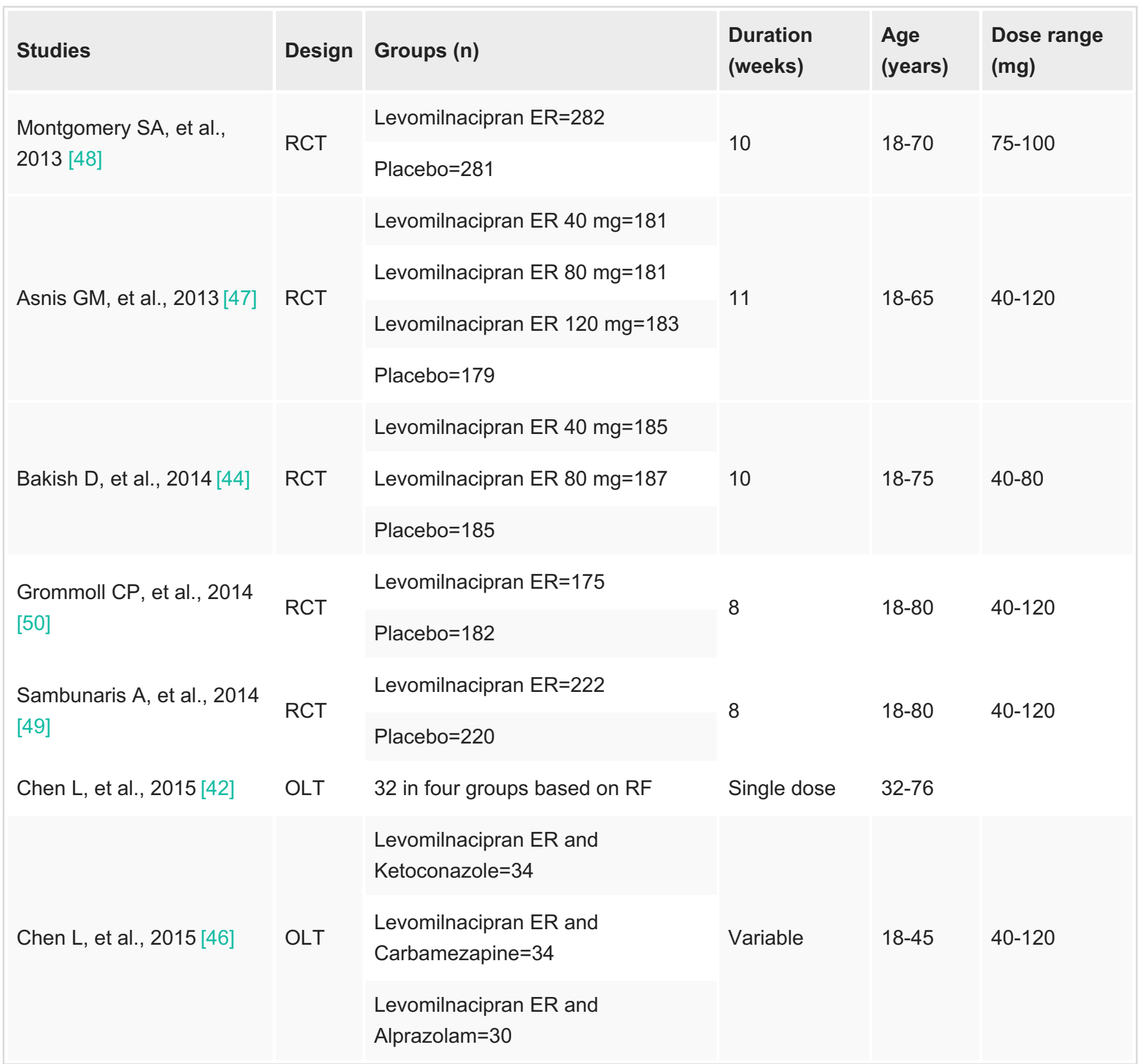

TABLE 7: Summary of demographic characteristics, dose ranges, and duration of studies of Levomilnacipran ER

ER: Extended release, OLT: Open-label trial, RCT: Randomized controlled trial, RF: Renal functioning 


\section{Cureus}

\section{Studies}

Montgomery SA, et al., 2013 [48]

Asnis GM, et al., 2013

[47]

Bakish D, et al., 2014

[44]

Grommoll CP, et al., 2014 [50]

Sambunaris A, et al., 2014 [49]

Chen L, et al., 2015 [42]

Chen L, et al., 2015 [46]

\section{Clinical outcomes}

Levomilnacipran ER had a favorable response for depression and functional impairment.

Significant improvement in depression at 80 and $120-\mathrm{mg}$ doses than in the 40-mg group. All doses were superior to placebo.

Levomilnacipran ER had a clinically significant improvement in depression and functional impairment for 40 and $80 \mathrm{mg}$ doses.

Levomilnacipran ER resulted in a greater reduction in depressive symptoms but was not statistically significant from placebo.

Levomilnacipran ER resulted in improvement of the depressive symptoms and functional impairment.

No dose adjustment is needed with mild renal impairment but need adjustments with moderate and severe impairment.

Dose reduction with ketoconazole and dose adjustment is needed with CYP3A4 inducers or alprazolam.

\section{TABLE 8: Summary of clinical outcomes of studies of Levomilnacipran ER}

ER: Extended release, No.: Number, RCT: Randomized controlled trial

\section{Safety and tolerability}

The safety of levomilnacipran SR for various dosages of 40, 80, and $120 \mathrm{mg}$ was assessed in an RCT. The most common treatment-emergent AEs, defined as $\geqslant 10 \%$ of any treatment group, were headache, nausea, constipation, dry mouth, increased heart rate, and hyperhidrosis. During double-blind treatment, serious AEs were reported in two patients (1.1\%) in the levomilnacipran ER 40-mg group (chest pain and deep vein thrombosis in one patient, and aggression in one patient) and one patient (0.6\%) in the $80-\mathrm{mg}$ group (cytomegalovirus mononucleosis). During medication taper, a new AE emerged; Nasopharyngitis which was more frequently reported in $40 \mathrm{mg}$ group (zero patients in the placebo group; three patients in the 40-mg group; one each in the 80-mg and 120-mg groups). Other AEs included increases in liver transaminases and a mild increase in blood pressure. Similar trends of AEs were reported in another RCT of two dosages 40 and $80 \mathrm{mg}$ [44]. Two patients in the levomilnacipran ER 40 $\mathrm{mg}$ /day group exited the study owing to serious AEs (intussusception, $\mathrm{n}=1$, and asthma, $\mathrm{n}=1$ ). No serious AEs were reported in the levomilnacipran ER $80 \mathrm{mg} /$ day group, and no serious AE was considered by the investigator to be treatment-related [47]. The AEs that occurred at an incidence of $5 \%$ or more and at least at twice the rate of placebo in both levomilnacipran ER groups were same as Asnis et al. but also included urinary hesitation and erectile dysfunction.

\section{Pregnancy}

Levomilnacipran lacks adequate and well-controlled studies in pregnant women. Neonates, in general, have complications due to dual reuptake inhibition of 5-HT and NE when they are exposed late in the third trimester. In animal studies, levomilnacipran ER was not teratogenic during the period of organogenesis. However, a decrease in fetal weight was observed [45]. 


\section{Discussion}

The prevalence of depression has increased in recent years due to increased awareness about the depression. Despite the availability of several effective antidepressants, only 30\% of patients take psychotropic medications as prescribed due to the presence of AEs, an absence of noticeable therapeutic effects for several weeks, and lack of response with the traditional antidepressants in some patients [5]. The first-line treatment of MDD includes administration of an SSRI, SNRIs, bupropion, and mirtazapine. However, the studies indicate that remission rates following two trials of an SSRI are less than $50 \%$. This is particularly important considering the monoamine theory of depression, suggesting the role of serotonin, norepinephrine, and/or dopamine. This article reviews relevant articles to provide a comprehensive overview of some novel antidepressants including desvenlafaxine, vortioxetine, vilazodone, and levomilnacipran ER.

Vilazodone is a $5 \mathrm{HT}_{1 \mathrm{~A}}$ partial agonistic and a serotonin transporter blockade. It is extensively metabolized mainly through CYP3A4 and should be taken with food. One study showed that patients taking Vilazodone did not report any sexual side effects as compared to placebo or citalopram group. Levomilnacipran, is another FDA approved new antidepressants, which acts as an SNRI but preferentially inhibit norepinephrine re-uptake as compared to other SNRIs.

Desvenlafaxine is an SNRI, with a higher affinity for serotonin transporter as compared to NE transporter. Along with an improvement in mood, it also results in improvement in the quality of life. The side effects and withdrawal symptoms need to be observed especially with higher doses. Vortioxetine works through various serotonin receptors and increases other neurotransmitters which help improvement in mood and cognition. It is metabolized through the liver and acts as a substrate mainly for CYP2D6. Because of its action on different receptors, there is a possibility of more side effects and withdrawal symptoms, which can lead to noncompliance with the treatment.

\section{Conclusions}

The multimodal mechanisms of actions of new antidepressants explain that depression may not be caused by the simple deficit of serotonin, but rather can be related to "flooding" $5 \mathrm{HT}_{1 \mathrm{~A}}$ autoreceptors in midbrain peri-raphe areas by serotonin itself through the action of glutamate, noradrenaline, and histamine. There is limited research on the use of the novel antidepressants in human subjects, and further studies are warranted to reveal substantial difference and other novel attributes of these new medications.

\section{Additional Information}

\section{Disclosures}

Conflicts of interest: In compliance with the ICMJE uniform disclosure form, all authors declare the following: Payment/services info: All authors have declared that no financial support was received from any organization for the submitted work. Financial relationships: All authors have declared that they have no financial relationships at present or within the previous three years with any organizations that might have an interest in the submitted work. Other relationships: All authors have declared that there are no other relationships or activities that could appear to have influenced the submitted work.

\section{References}

1. Kessler RC, Bromet EJ: The epidemiology of depression across cultures . Ann Rev Public Health. 2013, 34:119-138. 10.1146/annurev-publhealth-031912-114409

2. Mathews M, Gommoll C, Chen D, Nunez R, Khan A: Efficacy and safety of vilazodone 20 and 
$40 \mathrm{mg}$ in major depressive disorder: a randomized, double-blind, placebo-controlled trial. Int Clin Psychopharmacol. 2015, 30:67-74. 10.1097/YIC.0000000000000057

3. Montgomery SA, Nielsen RZ, Poulsen LH, Häggström L: A randomised, double-blind study in adults with major depressive disorder with an inadequate response to a single course of selective serotonin reuptake inhibitor or serotonin-noradrenaline reuptake inhibitor treatment switched to vortioxetine or agomelatine. Hum Psychopharmacol. 2014, 29:470-82. 10.1002/hup.2424

4. Florea I, Danchenko N, Brignone M, Loft H, Rive B, Abetz-Webb L: The effect of vortioxetine on health-related quality of life in patients with major depressive disorder. Clin Ther. 2015, 37:2309-232. 10.1016/j.clinthera.2015.08.008

5. Elizabeth P, Tracy DK: The drugs don't work? antidepressants and the current and future pharmacological management of depression. Ther Adv Psychopharmacol. 2012, 2:179-188. $10.1177 / 2045125312445469$

6. Feiger, AD, Tourian, KA, Rosas GR, Padmanabhan SK: A placebo-controlled study evaluating the efficacy and safety of flexible-dose desvenlafaxine treatment in outpatients with major depressive disorder. CNS Spectr. 2009, 14:41-50. 10.1017/S1092852900020046

7. Highlights of prescribing information. (2011). Accessed: December 17, 2018: https://www.accessdata.fda.gov/drugsatfda_docs/label/2012/021992s030lbl.pdf.

8. Deecher DC, Beyer CE, Johnston G, Bray J, Shah S, Abou-Gharbia M, Andree TH: Desvenlafaxine succinate: a new serotonin and norepinephrine reuptake inhibitor . J Pharmacol Exp Ther. 2006, 318:657-665. 10.1124/jpet.106.103382

9. Findling RL, Groark J, Tourian KA, Ramaker SA, Chiles D, Yang L, Nichols AI: Pharmacokinetics and tolerability of single-ascending doses of desvenlafaxine administered to children and adolescents with major depressive disorder. J Child Adolesc Psychopharmacol. 2016, 26:909-921. 10.1089/cap.2016.0009

10. Clayton AH, Kornstein SG, Dunlop BW, Focht K, Musgnung J, Ramey T, Ninan PT: Efficacy and safety of desvenlafaxine $50 \mathrm{mg} / \mathrm{d}$ in a randomized, placebo-controlled study of perimenopausal and postmenopausal women with major depressive disorder. J Clin Psychiatry. 2013, 26:909-921. 10.4088/JCP.12m08065

11. DeMartinis NA, Yeung PP, Entsuah R, Manley AL: A double-blind, placebo-controlled study of the efficacy and safety of desvenlafaxine succinate in the treatment of major depressive disorder. J Clin Psychiatry. 2007, 68:677-688.

12. Dunlop BW, Reddy S, Yang L, Lubaczewski S, Focht K, Guico-Pabia CJ: Symptomatic and functional improvement in employed depressed patients: a double-blind clinical trial of desvenlafaxine versus placebo. J Clin Psychopharmacol. 2011, 31:569-576.

10.1097/JCP.0b013e31822c0a68

13. Ferguson JM, Tourian KA, Rosas GR: High-dose desvenlafaxine in outpatients with major depressive disorder. CNS Spectr. 2012, 17:121-130. 10.1017/S1092852912000508

14. Septien-Velez L, Pitrosky B, Padmanabhan SK, Germain JM, Tourian KA: A randomized, double-blind, placebo-controlled trial of desvenlafaxine succinate in the treatment of major depressive disorder. Int Clin Psychopharmacol. 2007, 22:338-347. 10.1097/YIC.0b013e3281e2c84b

15. Boyer P, Montgomery S, Lepola U, Germain JM, Brisard C, Ganguly R, Tourian KA: Efficacy, safety, and tolerability of fixed-dose desvenlafaxine 50 and $100 \mathrm{mg} /$ day for major depressive disorder in a placebo-controlled trial. Int Clin Psychopharmacol. 2008, 23:243-253.

10.1097/YIC.0b013e32830cebed

16. Liebowitz MR, Manley AL, Padmanabhan SK, Ganguly R, Tummala R, Tourian KA: Efficacy, safety, and tolerability of desvenlafaxine $50 \mathrm{mg} /$ day and $100 \mathrm{mg}$ /day in outpatients with major depressive disorder. Curr Med Res Opin. 2008, 24:1877-1890. 10.1185/03007990802161923

17. Liebowitz MR, Yeung PP, Entsuah R: A randomized, double-blind, placebo-controlled trial of desvenlafaxine succinate in adult outpatients with major depressive disorder. J Clin Psychiatry. 2007, 68:1663-1672.

18. Fábregas B, Moura A, Ávila R, Carmo R, Teixeira AL: Serotonin-norepinephrine reuptake inhibitor desvenlafaxine for the treatment of interferon alfa-associated depression in patients with hepatitis C. Braz J Psychiatry. 2014, 36:183. 10.1590/1516-4446-2013-1210

19. Feinberg SS: Correction of venlafaxine-and duloxetine-induced transaminase elevations with desvenlafaxine in a patient with Gilbert's syndrome. CNS Spectr. 2010, 15:53-55.

$10.1017 /$ S1092852900000304 
20. Findling RL, Groark J, Chiles D, Ramaker S, Yang L, Tourian KA: Safety and tolerability of desvenlafaxine in children and adolescents with major depressive disorder. J Child Adolesc Psychopharmacol. 2014, 24:201-209. 10.1089/cap.2012.0126

21. Clayton AH, Kornstein SG, Rosas G, Guico-Pabia C, Tourian KA: An integrated analysis of the safety and tolerability of desvenlafaxine compared with placebo in the treatment of major depressive disorder. CNS Spectr. 2009, 14:183-195. 10.1017/S1092852900020204

22. Highlights of prescribing information. (2013). Accessed: December 20, 2018: https://www.accessdata.fda.gov/drugsatfda_docs/label/2013/204447s000lbl.pdf.

23. Baldwin DS, Loft H, Dragheim M: A randomised, double-blind, placebo-controlled, duloxetine-referenced, fixed-dose study of three dosages of Lu AA21004 in acute treatment of major depressive disorder (MDD). Eur Neuropsychopharmacol. 2012, 22:482-491. 10.1016/j.euroneuro.2011.11.008

24. Bang-Andersen B, Ruhland T, Jørgensen M, Smith G, Frederiksen K, Jensen KG, Stensbøl TB: Discovery of 1-[2-(2, 4-dimethylphenylsulfanyl) phenyl] piperazine (Lu AA21004): a novel multimodal compound for the treatment of major depressive disorder. J Med Chem. 2011, 54:3206-3221. 10.1021/jm101459g

25. Alvarez E, Perez V, Dragheim M, Loft H, Artigas F: A double-blind, randomized, placebocontrolled, active reference study of Lu AA21004 in patients with major depressive disorder. Int J Neuropsychopharmacol. 2012, 15:589-600. 10.1017/S1461145711001027

26. Chen G, Zhang W, Serenko M: Lack of effect of multiple doses of vortioxetine on the pharmacokinetics and pharmacodynamics of aspirin and warfarin. J Clin Pharmacol. 2015, 55:671-679. 10.1002/jcph.456

27. Boulenger JP, Loft H, Olsen CK: Efficacy and safety of vortioxetine (Lu AA21004), 15 and 20 $\mathrm{mg} /$ day: a randomized, double-blind, placebo-controlled, duloxetine-referenced study in the acute treatment of adult patients with major depressive disorder. Int Clin Psychopharmacol. 2014, 29:138. 10.1097/YIC.0000000000000018

28. Jacobsen PL, Mahableshwarkar AR, Serenko M, Chan S, Trivedi MH: A randomized, doubleblind, placebo-controlled study of the efficacy and safety of vortioxetine $10 \mathrm{mg}$ and $20 \mathrm{mg}$ in adults with major depressive disorder. J Clin Psychiatry. 2015, 76:575-582.

10.4088/JCP.14m09335

29. Mahableshwarkar AR, Jacobsen PL, Serenk M, Chen Y, Trivedi MH: A randomized, doubleblind, placebo-controlled study of the efficacy and safety of 2 doses of vortioxetine in adults with major depressive disorder. J Clin Psychiatry. 2015, 76:583-591. 10.4088/JCP.14m09337

30. Boulenger JP, Loft H, Florea I: A randomized clinical study of Lu AA21004 in the prevention of relapse in patients with major depressive disorder. J Psychopharmacol. 2012, 26:1408-1416. $10.1177 / 0269881112441866$

31. Jain R, Mahableshwarkar AR, Jacobsen PL, Chen Y, Thase ME: A randomized, double-blind, placebo-controlled 6-wk trial of the efficacy and tolerability of $5 \mathrm{mg}$ vortioxetine in adults with major depressive disorder. Int J Neuropsychopharmacol. 2013, 16:313-321. 10.1017/S1461145712000727

32. McIntyre RS, Lophaven S, Olsen CK: A randomized, double-blind, placebo-controlled study of vortioxetine on cognitive function in depressed adults. Int J Neuropsychopharmacol. 2014, 17:1557-1567. 10.1017/S1461145714000546

33. Mahableshwarkar AR, Jacobsen PL, Chen Y: A randomized, double-blind trial of $2.5 \mathrm{mg}$ and 5 mg vortioxetine (Lu AA21004) versus placebo for 8 weeks in adults with major depressive disorder. Curr Med Res Opin. 2013, 29:217-226. 10.1185/03007995.2012.761600

34. Alam MY, Jacobsen PL, Chen Y, Serenko M, Mahableshwarkar AR: Safety, tolerability, and efficacy of vortioxetine (Lu AA21004) in major depressive disorder: results of an open-label, flexible-dose, 52-week extension study. Int Clin Psychopharmacol. 2014, 29:36-44. 10.1097/YIC.0000000000000010

35. Highlights of prescribing information. (2011). Accessed: December 25, 2018: https://www.accessdata.fda.gov/drugsatfda_docs/label/2011/022567s001lbl.pdf.

36. Boinpally R, Gad N, Gupta S, Periclou A: Influence of CYP3A4 induction/inhibition on the pharmacokinetics of vilazodone in healthy subjects. Clin Ther. 2014, 36:1638-1649. 10.1016/j.clinthera.2014.08.003

37. Rickels K, Athanasiou M, Robinson DS, Gibertini M, Whalen H, Reed CR: Evidence for efficacy and tolerability of vilazodone in the treatment of major depressive disorder: a randomized, double-blind, placebo-controlled trial. J Clin Psychiatry. 2009, 70:326-333. 


\subsection{8/JCP.08m04637}

38. Khan A, Cutler AJ, Kajdasz DK., Gallipoli S, Athanasiou M, Robinson DS, Reed CR: A randomized, double-blind, placebo-controlled, 8-week study of vilazodone, a serotonergic agent for the treatment of major depressive disorder. J Clin Psychiatry. 2011, 72:441-447. 10.4088/JCP.10m06596

39. Croft HA, Pomara N, Gommoll C, Chen D, Nunez R, Mathews M: Efficacy and safety of vilazodone in major depressive disorder: a randomized, double-blind, placebo-controlled trial. J Clin Psychiatry. 2014, 75:1291-1298. 10.4088/JCP.14m08992

40. Grant JE, Redden SA, Leppink EW: Double-blind switch study of vilazodone in the treatment of major depressive disorder. Int Clin Psychopharmacol. 2017, 32:121-126. 10.1097/YIC.0000000000000166

41. Rele S, Millet R, Kim S, Paik JW, Kim S, Masand PS, Patkar AA: An 8-week randomized, double-blind trial comparing efficacy, safety, and tolerability of 3 vilazodone dose-initiation strategies following switch from SSRIs and SNRIs in major depressive disorder. Prim Care Companion CNS Disord. 2015, 6;17(4):10.4088/PCC.14m01734

42. Chen L, Boinpally R, Gad N, Greenberg WM, Wangsa J, Periclou A, Ghahramani P: Evaluation of cytochrome P450 (CYP) 3A4-based interactions of levomilnacipran with ketoconazole, carbamazepine or alprazolam in healthy subjects. Clin Drug Investig. 2015, 35:601-612. 10.1007/s40261-015-0318-2

43. Chen L, Greenberg WM, Gommoll C, O’Connor J, Zukin SR, Periclou A, Ghahramani P: Levomilnacipran pharmacokinetics in healthy volunteers versus patients with major depressive disorder and implications for norepinephrine and serotonin reuptake inhibition. Clin Ther. 2015, 37:2059-2070. 10.1016/j.clinthera.2015.07.005

44. Bakish D, Bose A, Gommoll C, Chen C, Nunez R, Greenberg WM, Khan A: Levomilnacipran ER $40 \mathrm{mg}$ and $80 \mathrm{mg}$ in patients with major depressive disorder: a phase III, randomized, doubleblind, fixed-dose, placebo-controlled study. J Psychiatry Neurosci. 2014, 39:40-49. 10.1503/jpn.130040

45. Highlights of prescribing information. (2009). Accessed: December 20, 2018: https://www.accessdata.fda.gov/drugsatfda_docs/label/2013/204168s000lbl.pdf.

46. Chen L, Greenberg WM, Brand-Schieber E, Wangsa J, Periclou A, Ghahramani P: Effect of renal impairment on the pharmacokinetics of levomilnacipran following a single oral dose of levomilnacipran extended-release capsule in humans. Drug Des Devel Ther. 2015, 25:32933300. 10.2147/DDDT.S85418

47. Asnis GM, Bose A, Gommoll CP, Chen, Greenberg: Efficacy and safety of levomilnacipran sustained release $40 \mathrm{mg}, 80 \mathrm{mg}$, or $120 \mathrm{mg}$ in major depressive disorder: a phase 3, randomized, double-blind, placebo-controlled study. J Clin Psychiatry. 2013, 74:242-248. 10.4088/JCP.12m08197

48. Montgomery SA, Mansuy L, Ruth A, Bose A, Li, Li D: Efficacy and safety of levomilnacipran sustained release in moderate to severe major depressive disorder: a randomized, doubleblind, placebo-controlled, proof-of-concept study. J Clin Psychiatry. 2013, 74:363-9. 10.4088/JCP.12m08141

49. Sambunaris A, Bose A, Gommoll CP, Chen C, Greenberg WM, Sheehan DV: A phase III, double-blind, placebo-controlled, flexible-dose study of levomilnacipran extended-release in patients with major depressive disorder. J Clin Psychopharmacol. 2014, 34:47-56. 10.1097/JCP.0000000000000060

50. Gommoll CP, Greenberg WM, Chen C: A randomized, double-blind, placebo-controlled study of flexible doses of levomilnacipran ER (40-120 mg/day) in patients with major depressive disorder. J Drug Assess. 2014, 16;3:10-19. 10.3109/21556660.2014.884505 